\title{
PI3K/mTOR and topoisomerase inhibitors with potential activity against SARS-CoV-2 infection
}

10

James Robert White, $\mathrm{PhD}^{1}$

5 Michael Bonner Foote, $\mathrm{MD}^{2}$

Justin Jee, MD, $\mathrm{PhD}^{2}$

Guillem Argilés, $\mathrm{MD}^{2}$

Jonathan C. M. Wan, MD, $\mathrm{PhD}^{2}$

Luis Alberto Diaz, Jr., $\mathrm{MD}^{2^{*}}$

${ }^{1}$ Resphera Biosciences, Baltimore, MD USA

${ }^{2}$ Department of Medicine, Memorial Sloan Kettering Cancer Center, New York, NY, USA

*Corresponding Author Information:

15 Luis Alberto Diaz Jr., Department of Medicine, Memorial Sloan Kettering Cancer Center, 1275 York Avenue, New York, NY 10065, USA; Phone: 1.646.888.5268; Email: diazl5@mskcc.org

\section{Abstract}

20 There is an urgent need to identify therapies to prevent and treat SARS-CoV-2 infection. We performed a statistical evaluation of in vitro gene expression profiles reflecting exposure to 1,835 drugs, and found topoisomerase inhibitors and $\mathrm{PI} 3 \mathrm{~K} / \mathrm{mTOR}$ pathway inhibitors among the strongest candidates for reduced expression of ACE2, a host gene associated with SARS-CoV-2 infection. Retrospective clinical data suggest that patients on these agents may be less likely to test positive for SARS-CoV-2. 
medRxiv preprint doi: https://doi.org/10.1101/2020.09.02.20186783; this version posted September 3, 2020. The copyright holder for this preprint (which was not certified by peer review) is the author/funder, who has granted medRxiv a license to display the preprint in perpetuity.

All rights reserved. No reuse allowed without permission.

\section{Introduction}

Severe acute respiratory syndrome coronavirus 2 (SARS-CoV-2) continues to spread globally with over 13.1 million diagnosed cases and 574,000 deaths (as of 14 July, 2020). SARS-CoV-2 is a single-stranded

30 RNA virus that utilizes spike (S) glycoproteins to infect individuals by attaching to angiotensin-converting enzyme 2 (encoded by the ACE2 gene) expressed on airway epithelia ${ }^{1-3}$. After attachment, hemagglutinin cleavage of ACE2 initiates viral internalization and subsequent viral S protein cleavage by the transmembrane protease serine 2 TMPRSS2 to enable viral entry ${ }^{3}$. Other transmembrane proteases, such as ADAM17 and TMPRSS11D, may also influence cleavage of ACE2 ${ }^{4,5}$.

ACE2 gene expression may provide a unique therapeutic target to help prevent SARS-CoV-2 infection. Hofman et al. found that ACE2 expression on a panel of cell lines correlated with in vitro susceptibility to SARS-CoV S-driven infection ${ }^{4}$. Many ACE2-associated factors, including TMPRSS2, have no recognized indispensable somatic functions; drugs targeting this pathway may show a promising therapeutic ratio ${ }^{6}$.

The Library of Integrated Network-Based Cellular Signatures (LINCS) program is an open resource for the scientific community that includes expression profiles of cells exposed to a variety of perturbing agents ${ }^{7}$ including small molecules over a range of concentrations. Here, we report on a comprehensive statistical evaluation of cell line gene expression signatures associated with various drug exposures in LINCS. We

45 analyzed 1,835 drugs for which distinct cells lines and variable dosages were available, and sought to identify those with statistically significant reductions in expression of genes associated with SARS-CoV-2 infection. We then utilized retrospective clinical data to evaluate whether cancer patients receiving drugs associated with reduced expression of ACE2 demonstrated a decreased odds ratio for a positive SARS$\mathrm{CoV}-2$ test compared to patients receiving other antineoplastic therapies. 
medRxiv preprint doi: https://doi.org/10.1101/2020.09.02.20186783; this version posted September 3, 2020. The copyright holder for this preprint (which was not certified by peer review) is the author/funder, who has granted medRxiv a license to display the preprint in perpetuity.

All rights reserved. No reuse allowed without permission.

\section{Results and Discussion}

For each drug, we fitted a generalized linear model to moderated Z-score values ${ }^{8}$ reflecting relative ACE2 gene expression across seven cell lines and drug dosages from $0.01 \mathrm{uM}$ to $10 \mathrm{uM}$ (Table S1). Among those

55 drugs with the strongest associated reductions in ACE2 expression, we identified two major categories: (i) topoisomerase inhibitors, and (ii) PI3K/mTOR pathway inhibitors (Table 1). Topoisomerase inhibitors including camptothecin, SN-38, and Genz-644282 demonstrated significant reductions in ACE2 expression, often with a dose dependent relationship (Fig. 1). PI3K/mTOR inhibitors including PF04691502, GDC-0980(RG7422), and Taselisib also displayed dose dependent reductions in ACE2

60 expression (Fig. 2). Moreover, two AKT inhibitors related to the PI3K/mTOR pathway, Afuresertib and MK-2206, were associated with reduced ACE2 (Table 1).

We next performed a retrospective review of clinical records to evaluate the frequency of SARS-CoV-2 infection in patients on these ACE2-associated antineoplastics. Retrospective data was obtained from an

65 IRB-approved study of adult cancer patients tested for SARS-CoV-2 receiving active antineoplastic therapy at Memorial Sloan Kettering Cancer Center (MSKCC) during the COVID-19 epidemic period ( $\mathrm{n}=4,040$ patients; Table S2). The overall study population had mainly solid tumors $(\mathrm{n}=3771 ; 93.3 \%)$. Thirteen percent $(\mathrm{n}=535)$ of the study population was actively treated with an ACE2-associated drug (Table S2, Table S5). Patients treated with ACE2-associated drugs showed similar clinical demographics to those 70 treated with different antineoplastics (Table S2).

Patients receiving ACE2-associated therapies demonstrated a lower univariate odds ratio $(0.65,95 \% \mathrm{CI}$ 0.00-0.98, $\mathrm{P}=0.04$ ) for a positive SARS-CoV-2 test during active antineoplastic therapy compared to patients on other agents (Table S3). Additional study covariates shown to be significant in cancer patients

75 were also evaluated. Patients with non-white race (OR 2.00), hematologic malignancy (OR 2.89) and metastatic disease (OR 1.49) also demonstrated statistically significant increase in the odds of a positive SARS-CoV-2 test (Table S3). Significant covariates were placed into a multivariate logistic regression 
medRxiv preprint doi: https://doi.org/10.1101/2020.09.02.20186783; this version posted September 3, 2020. The copyright holder for this preprint (which was not certified by peer review) is the author/funder, who has granted medRxiv a license to display the preprint in perpetuity.

All rights reserved. No reuse allowed without permission.

model (Table S4). Active therapy trended towards independent significance for a SARS-CoV-2 positive test (OR 0.68, 95\% CI 0.40-1.07, BH-corrected q=0.13).

80

Our results reveal several antineoplastic agents that may demonstrate reductions in ACE2 expression, a potential target proposed in preventing and treating SARS-CoV-2 infection. Cancer patients taking these potential ACE2-associated agents showed lower rates of a positive SARS-CoV-2 test compared to patients taking other forms of active antineoplastic therapy. These medications were universally held when patients

85 tested positive for SARS-CoV-2, and our study was underpowered to detect possible differences in COVID19 associated endpoints, such as admission, hypoxic events and death.

These findings are consistent with recent studies that propose topoisomerase inhibitors or PI3K/mTOR inhibitors for treatment of COVID-19. One recent study proposed Irinotecan and Etoposide combination

90 therapy for critically ill COVID-19 patients $^{9}$ based on the immunomodulatory and viral suppressive profiles of these drugs. Additionally, a recent loss-of-function experiment revealed that certain topoisomerases were required for efficient replication of positive-sense RNA viruses including SARS-CoV- $2^{10}$. Immunoregulatory and anti-viral properties have also been cited as rationales for PI3K/mTOR pathway inhibitors to treat COVID-19 $9^{11-17}$.

This study has several limitations. ACE2-associated antineoplastic therapies were discovered by in-vitro computer modeling and need to be validated experimentally. Although in vitro data implicates ACE2 in the SARS-CoV-2 infection route, ACE2 is not yet a clinically validated target. Furthermore, clinical data obtained were retrospective and may be underpowered to estimate the true impact of ACE2-associated 100 therapy on SARS-CoV-2 positivity and COVID-19 adverse outcomes. Finally, study patient characteristics are skewed towards non-metastatic $(63.2 \%)$, solid tumor $(93.3 \%)$ patients. Despite these limitations, our results suggest that further investigation of $\mathrm{PI} 3 \mathrm{~K} / \mathrm{mTOR}$ pathway inhibitors and topoisomerase inhibitors as a COVID-19 preventative strategy are warranted. 
medRxiv preprint doi: https://doi.org/10.1101/2020.09.02.20186783; this version posted September 3, 2020. The copyright holder for this preprint (which was not certified by peer review) is the author/funder, who has granted medRxiv a license to display the preprint in perpetuity.

All rights reserved. No reuse allowed without permission.

\section{Methods}

105 In Vitro Modeling and Analysis. LINCS gene expression signatures and associated drug exposure metadata were collected using the LINCS Data Portal API (http://lincsportal.ccs.miami.edu/apis). Compounds considered were limited to those tested on the seven specific cell lines of interest with 24 hours of exposure time at concentrations ranging from $0.01 \mathrm{uM}$ to $10 \mathrm{uM}$. For each candidate drug, a generalized linear model was fit to ACE2 moderated Z-scores values adjusted for log10(drug concentration). Calculated

110 by LINCS, moderated Z-scores reflect a weighted average of replicate samples in an experiment of a specific cell line and drug concentration. Model coefficients and P-values associated with baseline expression and drug concentration (two-sided test; null hypothesis $\beta=0$ ) were used to prioritize drugs with significant reductions in ACE2 expression and dose dependent relationships. P-values were adjusted for multiple hypothesis testing using the false discovery rate (FDR).

Data Availability. LINCS Phase I data are publicly available through NCBI (GEO accession GSE92742) and the LINCS Data Portal 2.0 (http://lincsportal.ccs.miami.edu/). Procedures on LINCS signature generation and moderated Z-score calculation can be found in the GEO LINCS user guide (v2.1; https://docs.google.com/document/d/1q2gciWRhVCAAnlvF2iRLuJ7whrGP6QjpsCMq1yWz7dU/edit\#).

120 Aggregated patient data used in this study is available upon request from the corresponding author (L.A.D.). Requests will be first reviewed for compliance with the ethical and patient privacy regulations of the Memorial Sloan Kettering Cancer Center.

Code Availability. The R code used for this study is available upon request from the corresponding author.

Clinical Data Acquisition and Definitions. Electronic medical record (EMR) auto-populated flowsheet data was obtained for adult cancer patients at Memorial Sloan Kettering Cancer Center (MSKCC) undergoing active antineoplastic treatment during the time of the first positive SARS-CoV-2 tests $(03 / 01 / 2020)$ with a study data freeze on 5/28/20 for analysis. Patients with antineoplastic therapies that 
130 were discontinued before this study period were not included in the study. Auto-populated flowsheet data was obtained from a standardized-input curated database that assessed the time and date of antineoplastic administration, as well as patient demographics, disease characteristics and study endpoints. SARS-CoV-2 testing was performed at MSKCC using a nasopharyngeal swab to determine the presence of virus specific RNA (MSKCC FDA-EUA-approved assay, and commercial assay Cephied®). Patients who had a positive

135 test were classified as SARS-CoV-2 positive. Patients who tested negative or were not tested for SARSCoV-2 were classified as "Not SARS-CoV-2 positive".

Study subgroups were classified as in Table S2. Notably, malignancy status as solid or hematologic was not mutually exclusive; several study patients had both an active solid and liquid malignancy, and were 140 thereby coded as having each separate subtype. Although most patients were coded for the study variables, several patients did not have coded demographics and these patients were not associated with their respective missing demographic. For example, $89.1 \%$ of patients were coded for tobacco status with $10.9 \%$ of patients with an unknown tobacco status; these patients were not associated with a tobacco status in the statistical analysis.

Antineoplastic therapies were grouped using standardized antineoplastic drug categories (Table S5). Antineoplastic agents with significant activity from in vitro assessment (Table 1) were cross-referenced against the study population to determine ACE2-associated therapy status. If a patient received an ACE2expression reducing therapy during the study period $(03 / 01 / 20-05 / 28 / 20)$, they were classified in the

150 "ACE2-associated antineoplastic" subgroup. Patients who did not receive a potential ACE2 expression reducing agent were classified in the "No ACE2-associated antineoplastic" subgroup.

Clinical Data Statistical Analysis. Univariate, one-sided Fisher's exact statistical testing was used to test the specific hypothesis that active ACE2-associated antineoplastic use is associated with a lower odds ratio 155 of a positive SARS-CoV-2 test. Additional study covariates (female gender, age greater than or equal to 
medRxiv preprint doi: https://doi.org/10.1101/2020.09.02.20186783; this version posted September 3, 2020. The copyright holder for this preprint (which was not certified by peer review) is the author/funder, who has granted medRxiv a license to display the preprint in perpetuity.

All rights reserved. No reuse allowed without permission.

65, non-white race, smoking, hematologic malignancy, metastatic disease) were similarly evaluated. Odds ratios, $95 \%$ confidence intervals, and one-sided p-values were reported for each covariate. Covariates with a p-value of less than or equal to 0.10 were placed into a multivariate model, and logistic regression was performed. To account for multiplicity, p-values for each covariate in the multivariate model were subject 160 to Benjamini-Hochberg correction and q-values were reported.

The odds ratios of achieving specific clinical endpoints, including admission, hypoxic event (defined as requiring greater than $4 \mathrm{~L}$ of oxygen), and death, were assessed comparing patients with ACE2-associated antineoplastics and patients who did not received ACE2-associated antineoplastics using similar Fisher's

165 exact statistical testing. No significant difference in adverse COVID-19 outcomes (admission, hypoxia requiring greater than 4 liters of supplementary oxygen, death, or composite of these three outcomes) was observed in the overall study population, or a subset population of only SARS-CoV-2 positive patients.

All statistical computation was done with use of R Studio (version 1.2.5033) and R (v4.0.0) statistical 170 software.

Study Approval. This study was approved by the Institutional Review Board at Memorial Sloan Kettering Cancer Center. 
medRxiv preprint doi: https://doi.org/10.1101/2020.09.02.20186783; this version posted September 3, 2020. The copyright holder for this preprint (which was not certified by peer review) is the author/funder, who has granted medRxiv a license to display the preprint in perpetuity.

All rights reserved. No reuse allowed without permission.

\section{Author contributions}

J.R.W. and L.A.D. conceived and designed the study. J.R.W. and M.B.F. analyzed and interpreted data.

J.J. and M.B.F. collected retrospective patient data. J.C.M.W. and A.G. provided guidance and scientific input. J.C.M.W. and A.G. interpreted results. J.R.W., J.C.M.W., and M.B.F. drafted the manuscript. All authors read and approved the final manuscript.

\section{Acknowledgements}

Research supported by a Stand Up to Cancer Colorectal Cancer Dream Team Translation Cancer Research Grant (SU2C-AACR-DT22-17). Stand up to Cancer is a program of the Entertainment Industry Foundation administered by the American Association for Cancer Research. M.B.F. is partially supported by a T32 NIH Scholar Grant.

\section{Conflict of Interest Statement}

JRW is the founder and owner of Resphera Biosciences, LLC. JJ holds a patent licensed by MDSeq, Inc. GA has received honoraria for advisory roles from Hoffman La-Roche, Bayer and Servier and honoraria for speaking engagements from Hoffman La-Roche, Bristol Myers Squibb, Bayer and Servier. GA has

195 received travel grants from Hoffman La-Roche, Bayer, Servier, Amgen and Merck and research funds have been awarded to GA from Bayer. GA is an uncompensated advisor for Menarini and Treos Bio, Inc. LAD is a member of the board of directors of Personal Genome Diagnostics (PGDx) and Jounce Therapeutics. LAD is a paid consultant to PGDx, 4Paws and Neophore. LAD is an uncompensated consultant for Merck but has received research support for clinical trials from Merck. LAD is an inventor of multiple licensed 200 patents related to technology for circulating tumor DNA analyses and mismatch repair deficiency for diagnosis and therapy from Johns Hopkins University. Some of these licenses and relationships are associated with equity or royalty payments directly to Johns Hopkins and LAD. LAD also holds equity in PGDx, Jounce Therapeutics, Thrive Earlier Detection and Neophore, and his spouse holds equity in Amgen. 
medRxiv preprint doi: https://doi.org/10.1101/2020.09.02.20186783; this version posted September 3, 2020. The copyright holder for this preprint (which was not certified by peer review) is the author/funder, who has granted medRxiv a license to display the preprint in perpetuity.

All rights reserved. No reuse allowed without permission.

The terms of these arrangements for LAD are being managed by Johns Hopkins and Memorial Sloan

205 Kettering in accordance with their conflict of interest policies.

\section{References}

1. Zhou, P. et al. A pneumonia outbreak associated with a new coronavirus of probable bat origin. Nature 579, 270-273 (2020).

2102 Walls, A. C. et al. Structure, Function, and Antigenicity of the SARS-CoV-2 Spike Glycoprotein. Cell 181, 281-292.e6 (2020).

3. Hoffmann, M. et al. SARS-CoV-2 Cell Entry Depends on ACE2 and TMPRSS2 and Is Blocked by a Clinically Proven Protease Inhibitor. Cell 181, 271-280.e8 (2020).

215 Augments Entry Driven by the Severe Acute Respiratory Syndrome Coronavirus Spike Protein. J. Virol. 88, 1293-1307 (2014).

5. $\quad$ Palau, V., Riera, M. \& Soler, M. J. ADAM17 inhibition may exert a protective effect on COVID-19. Nephrol. Dial. Transplant (2020) doi:10.1093/ndt/gfaa093.

220 19: Serendipity or Opportunity for Intervention? Cancer Discov. 10, 779-782 (2020).

7. Keenan, A. B. et al. The Library of Integrated Network-Based Cellular Signatures NIH Program: SystemLevel Cataloging of Human Cells Response to Perturbations. Cell Systems vol. 6 13-24 (2018).

8. Subramanian, A. et al. A Next Generation Connectivity Map: L1000 Platform and the First 1,000,000 Profiles. Cell (2017) doi:10.1016/j.cell.2017.10.049.

225 9. Lovetrue, B. The AI-discovered Aetiology of COVID-19 and Rationale of the Irinotecan + Etoposide Combination Therapy for Criti- cally Ill COVID-19 Patients. 1-18 (2020) doi:10.20944/preprints202003.0341.v1.

10. Prasanth, K. R. et al. Topoisomerase III- $\beta$ is required for efficient replication of positive-sense RNA viruses. bioRxiv 2020.03.24.005900 (2020) doi:10.1101/2020.03.24.005900.

230 11. Lehrer, S. Inhaled biguanides and mTOR inhibition for influenza and coronavirus (Review). World Acad. Sci. J. 2, 1-1 (2020).

12. Ciliberto, G., Mancini, R. \& Paggi, M. G. Drug repurposing against COVID-19: Focus on anticancer agents. Journal of Experimental and Clinical Cancer Research vol. 39 1-9 (2020).

13. Zheng, Y., Li, R. \& Liu, S. Immunoregulation with mTOR inhibitors to prevent COVID-19 severity: A (2020) doi:10.1002/jmv.26009.

14. Kindrachuk, J. et al. Antiviral potential of ERK/MAPK and PI3K/AKT/mTOR signaling modulation for Middle East respiratory syndrome coronavirus infection as identified by temporal kinome analysis. Antimicrob. Agents Chemother. 59, 1088-1099 (2015).

240 15. Zhou, Y. et al. Network-based drug repurposing for novel coronavirus 2019-nCoV/SARS-CoV-2. Cell Discov. 6, 1-18 (2020).

16. Terrazzano, G. et al. An Open Question: Is It Rational to Inhibit the mTor-Dependent Pathway as COVID19 Therapy? Front. Pharmacol. 11, 856 (2020).

245 CoV. bioRxiv 2020.06.17.156455 (2020) doi:10.1101/2020.06.17.156455. 
medRxiv preprint doi: https://doi.org/10.1101/2020.09.02.20186783; this version posted September 3, 2020. The copyright holder for this preprint (which was not certified by peer review) is the author/funder, who has granted medRxiv a license to display the preprint in perpetuity.

All rights reserved. No reuse allowed without permission.

\section{Tables and Figures}

Table 1. Classes of drugs commonly identified as reducers of ACE2 expression. Generalized fixed effects model results reported per drug including coefficient for ACE2 expression (baseline) and associated with drug dose relationship. "N/A" designates "Not Applicable". Unadjusted and false discovery rate (FDR) adjusted P-values are included.

\begin{tabular}{|c|c|c|c|c|c|c|c|}
\hline Drug & Annotation & $\begin{array}{l}\text { Coefficient } \\
\text { for change } \\
\text { in ACE2 }\end{array}$ & $\begin{array}{c}\text { P-value } \\
\text { for } \\
\text { change in } \\
\text { ACE2 }\end{array}$ & $\begin{array}{l}\text { FDR adj. } \\
\text { P-value } \\
\text { for } \\
\text { change in } \\
\text { ACE2 }\end{array}$ & $\begin{array}{l}\text { Coefficient } \\
\text { for dose } \\
\text { relationship }\end{array}$ & $\begin{array}{l}\text { P-value for } \\
\text { dose } \\
\text { relationship }\end{array}$ & $\begin{array}{l}\text { FDR adj. } \\
\text { P-value for } \\
\text { dose } \\
\text { relationship }\end{array}$ \\
\hline SN-38 & topoisomerase inhibitor & -1.57 & $<0.0001$ & $<0.0001$ & -0.59 & $<0.0001$ & 0.0191 \\
\hline Genz-644282 & topoisomerase inhibitor & -1.31 & $<0.0001$ & $<0.0001$ & -0.24 & 0.2118 & 0.6896 \\
\hline Camptothecin & topoisomerase inhibitor & -1.08 & $<0.0001$ & 0.0004 & 0.20 & 0.4281 & 0.8264 \\
\hline Topotecan & topoisomerase inhibitor & -0.31 & 0.7487 & 0.8785 & NA & NA & NA \\
\hline $\begin{array}{l}\text { Trovafloxacin } \\
\text { mesylate }\end{array}$ & topoisomerase inhibitor & -0.27 & 0.0255 & 0.1617 & -0.61 & 0.0001 & 0.0191 \\
\hline Aphidicolin & topoisomerase inhibitor & -0.23 & 0.0280 & 0.1686 & -0.28 & 0.0234 & 0.3135 \\
\hline Irinotecan & topoisomerase inhibitor & -0.18 & 0.0607 & 0.2439 & -0.13 & 0.2464 & 0.7079 \\
\hline Etoposide & topoisomerase inhibitor & -0.18 & 0.1455 & 0.3880 & -0.38 & 0.0102 & 0.2395 \\
\hline Adarotene & $\begin{array}{c}\text { apoptosis / dna damage } \\
\text { inducer }\end{array}$ & -0.57 & $<0.0001$ & 0.0002 & -0.48 & 0.0003 & 0.0472 \\
\hline Temsirolimus & mTOR inhibitor & -0.38 & 0.0003 & 0.0078 & -0.28 & 0.0149 & 0.2764 \\
\hline TORIN-2 & mTOR inhibitor & -0.68 & $<0.0001$ & 0.0010 & -0.27 & 0.0928 & 0.5307 \\
\hline AZD-8055 & mTOR inhibitor & -0.24 & 0.0021 & 0.0360 & -0.19 & 0.0355 & 0.3727 \\
\hline Everolimus & mTOR inhibitor & -0.32 & 0.0048 & 0.0606 & 0.00 & 0.9871 & 0.9986 \\
\hline MLN-0128 & mTOR inhibitor & -0.53 & $<0.0001$ & $<0.0001$ & -0.26 & 0.0119 & 0.2593 \\
\hline Taselisib & PI3K inhibitor & -0.56 & $<0.0001$ & 0.0002 & -0.39 & 0.0018 & 0.1289 \\
\hline Pictilisib & PI3K inhibitor & -0.28 & 0.0001 & 0.0022 & -0.09 & 0.2280 & 0.6940 \\
\hline $\begin{array}{c}\text { PI3-K mTOR } \\
\text { Inhibitor III } \\
\end{array}$ & PI3K/mTOR inhibitor & -0.52 & $<0.0001$ & 0.0003 & -0.52 & $<0.0001$ & 0.0191 \\
\hline PF-04691502 & PI3K/mTOR inhibitor & -0.77 & $<0.0001$ & $<0.0001$ & -0.43 & 0.0003 & 0.0430 \\
\hline GSK1059615 & PI3K/mTOR inhibitor & -0.57 & $<0.0001$ & $<0.0001$ & -0.37 & $<0.0001$ & 0.0001 \\
\hline $\begin{array}{c}\text { GDC- } \\
0980(\text { RG7422) }\end{array}$ & PI3K/mTOR inhibitor & -0.38 & 0.0001 & 0.0042 & -0.36 & 0.0013 & 0.1081 \\
\hline $\begin{array}{c}\text { UNII- } \\
\text { CVL1685GPH }\end{array}$ & PI3K/mTOR inhibitor & -0.37 & 0.0023 & 0.0387 & -0.33 & 0.0170 & 0.2804 \\
\hline EX-8678 & PI3K/mTOR inhibitor & -0.57 & 0.0004 & 0.0106 & 0.02 & 0.8838 & 0.9748 \\
\hline Afuresertib & AKT inhibitor & -0.51 & $<0.0001$ & 0.0010 & -0.31 & 0.0157 & 0.2780 \\
\hline MK-2206 & AKT inhibitor & -0.28 & 0.0012 & 0.0249 & 0.01 & 0.9510 & 0.9931 \\
\hline
\end{tabular}

\section{Supp Table. S1 | Differential expression results for ACE2 (LINCS Phase I data) using moderated Z-score signature measures of relative expression.}


medRxiv preprint doi: https://doi.org/10.1101/2020.09.02.20186783; this version posted September 3, 2020. The copyright holder for this preprint (which was not certified by peer review) is the author/funder, who has granted medRxiv a license to display the preprint in perpetuity.

All rights reserved. No reuse allowed without permission.

Supp Table. S2 | Summary of overall study patient characteristics. Demographic, clinical and treatment characteristics of all study patients, stratified into subgroups by ACE2-associated antineoplastic therapy status are reported. *ACE2-associated therapies and other anti-neoplastic therapies are not mutually exclusive; patients within the subgroup could be exposed to multiple agents during the study period. "N/A" designates "Not Applicable".

\begin{tabular}{|c|c|c|c|}
\hline & All (n=4040) & $\begin{array}{c}\text { No ACE2-associated } \\
\text { antineoplastic(n=3505) }\end{array}$ & $\begin{array}{l}\text { ACE2-associated antineoplastic } \\
(n=535)\end{array}$ \\
\hline & $\begin{array}{c}\text { No. (\% Total } \\
\text { Patients) }\end{array}$ & No. $(\%$ Column $)$ & No. $(\%$ Column $)$ \\
\hline \multicolumn{4}{|l|}{ Demographics } \\
\hline Female & $2406(59.6 \%)$ & $2095(59.8 \%)$ & $311(58.1 \%)$ \\
\hline Male & $1634(40.4 \%)$ & $1410(40.2 \%)$ & $224(41.9 \%)$ \\
\hline White & $3179(78.7 \%)$ & $2753(78.6 \%)$ & $426(79.6 \%)$ \\
\hline Non-White & $703(17.4 \%)$ & $613(17.5 \%)$ & $90(16.8 \%)$ \\
\hline Age $\geq 65$ & $2034(50.3 \%)$ & $1786(51.0 \%)$ & $248(46.4 \%)$ \\
\hline Age $<65$ & $2006(49.7 \%)$ & $1719(49.1 \%)$ & $287(53.6 \%)$ \\
\hline Tobacco former or current smoker & $2034(50.3 \%)$ & $1786(51.0 \%)$ & $248(46.4 \%)$ \\
\hline Never smoked tobacco & $2006(49.7 \%)$ & $1719(49.1 \%)$ & $287(53.6 \%)$ \\
\hline \multicolumn{4}{|l|}{ Cancer Overview } \\
\hline Solid malignancy* & $3771(93.3 \%)$ & $3273(93.4 \%)$ & $498(93.1 \%)$ \\
\hline Hematologic malignancy* & $269(6.7 \%)$ & $232(6.6 \%)$ & $37(6.9 \%)$ \\
\hline Metastatic disease & $1485(36.8 \%)$ & $1305(37.2 \%)$ & $180(33.6 \%)$ \\
\hline Non-metastatic disease & $2555(63.2 \%)$ & $2200(62.8 \%)$ & $355(66.4 \%)$ \\
\hline \multicolumn{4}{|l|}{ Outcomes } \\
\hline SARS-CoV-2 positive & $207(5.1 \%)$ & $188(5.4 \%)$ & $19(3.6 \%)$ \\
\hline Not SARS-CoV-2 positive & $3833(94.9 \%)$ & $3317(94.7 \%)$ & $516(96.4 \%)$ \\
\hline Admission & $559(13.8 \%)$ & $452(12.9 \%)$ & $107(20.0 \%)$ \\
\hline Hypoxic event & $69(1.7 \%)$ & $52(1.5 \%)$ & $17(3.2 \%)$ \\
\hline Death & $133(3.3 \%)$ & $110(3.1 \%)$ & $23(4.3 \%)$ \\
\hline \multicolumn{4}{|l|}{ ACE2-associated therapy* } \\
\hline Topotecan & $18(0.4 \%)$ & $\mathrm{N} / \mathrm{A}$ & $18(3.4 \%)$ \\
\hline Irinotecan & $281(7.0 \%)$ & N/A & $281(52.5 \%)$ \\
\hline Etoposide & $74(1.8 \%)$ & N/A & $74(13.8 \%)$ \\
\hline Temsirolimus & $6(0.1 \%)$ & N/A & $6(1.1 \%)$ \\
\hline Everolimus & $151(3.7 \%)$ & N/A & $151(28.2 \%)$ \\
\hline Alpelisib & $59(1.5 \%)$ & N/A & $59(11.0 \%)$ \\
\hline Duvelisib & $7(0.2 \%)$ & N/A & $7(1.3 \%)$ \\
\hline Idelalisib & $2(0.1 \%)$ & $\mathrm{N} / \mathrm{A}$ & $2(0.4 \%)$ \\
\hline MLN-0128 & $1(0.1 \%)$ & $\mathrm{N} / \mathrm{A}$ & $1(0.2 \%)$ \\
\hline Ipasertib & $1(0.1 \%)$ & $\mathrm{N} / \mathrm{A}$ & $1(0.2 \%)$ \\
\hline AZD5363 & $3(0.1 \%)$ & $\mathrm{N} / \mathrm{A}$ & $3(0.6 \%)$ \\
\hline Other anti-neoplastic therapy * & & & \\
\hline
\end{tabular}


medRxiv preprint doi: https://doi.org/10.1101/2020.09.02.20186783; this version posted September 3, 2020. The copyright holder for this preprint (which was not certified by peer review) is the author/funder, who has granted medRxiv a license to display the preprint in perpetuity.

All rights reserved. No reuse allowed without permission.

\begin{tabular}{|c|c|c|c|}
\hline Alkylating agents & $601(12.3 \%)$ & $601(17.1 \%)$ & N/A \\
\hline Anti-CTLA-4 monoclonal antibodies & $55(1.1 \%)$ & $55(1.6 \%)$ & N/A \\
\hline Anti-PD-1 monoclonal antibodies & $654(13.4 \%)$ & $654(18.6 \%)$ & N/A \\
\hline Antimetabolites & $802(16.4 \%)$ & $802(22.9 \%)$ & N/A \\
\hline Antineoplastic antibiotics & $186(3.8 \%)$ & $186(5.3 \%)$ & N/A \\
\hline Multidrug formulations & $15(0.3 \%)$ & $15(0.4 \%)$ & N/A \\
\hline BCR-ABL tyrosine kinase inhibitors & $65(1.3 \%)$ & $65(1.9 \%)$ & N/A \\
\hline BTK inhibitors & $34(0.7 \%)$ & $34(1.0 \%)$ & N/A \\
\hline CD20 monoclonal antibodies & $19(0.4 \%)$ & $19(0.5 \%)$ & N/A \\
\hline CD30 monoclonal antibodies & $11(0.2 \%)$ & $11(0.3 \%)$ & N/A \\
\hline CD38 monoclonal antibodies & $38(0.8 \%)$ & $38(1.1 \%)$ & N/A \\
\hline CDK 4/6 inhibitors & $291(6.0 \%)$ & $291(8.3 \%)$ & N/A \\
\hline EGFR inhibitors & $195(4.0 \%)$ & $195(5.6 \%)$ & N/A \\
\hline Hedgehog pathway inhibitors & $2(0.1 \%)$ & $2(0.1 \%)$ & N/A \\
\hline HER2 inhibitors & $223(4.6 \%)$ & $223(6.4 \%)$ & N/A \\
\hline Histone deacetylase inhibitors & $2(0.1 \%)$ & $2(0.1 \%)$ & N/A \\
\hline Mitotic inhibitors & $523(10.7 \%)$ & $523(14.9 \%)$ & N/A \\
\hline Multikinase inhibitors & $388(8.0 \%)$ & $388(11.1 \%)$ & N/A \\
\hline Other antineoplastic & $559(13.8 \%)$ & $559(16.0 \%)$ & N/A \\
\hline Oral immunomodulatory & $107(2.2 \%)$ & $107(3.0 \%)$ & N/A \\
\hline PARP inhibitors & $133(2.7 \%)$ & $133(3.8 \%)$ & N/A \\
\hline Proteasome inhibitors & $47(1.0 \%)$ & $47(1.3 \%)$ & N/A \\
\hline Topical chemotherapy & $17(0.3 \%)$ & $17(0.5 \%)$ & N/A \\
\hline VEGF/VEGFR inhibitors & $330(6.8 \%)$ & $330(9.4 \%)$ & N/A \\
\hline
\end{tabular}


medRxiv preprint doi: https://doi.org/10.1101/2020.09.02.20186783; this version posted September 3, 2020. The copyright holder for this preprint (which was not certified by peer review) is the author/funder, who has granted medRxiv a license to display the preprint in perpetuity.

All rights reserved. No reuse allowed without permission.

Supp Tab. S3 | Univariate analysis of patients receiving active antineoplastic therapy establishes odds ratios for a SARS-CoV-2 positive test for study covariates. Univariate analysis of study covariates demonstrates a significant decreased odds ratio for a SARS-CoV-2 positive test in patients with receiving ACE2-associated antineoplastic therapy (OR 0.65, 95\% CI 0.00-0.98, p-value 0.04).

\begin{tabular}{|c|c|c|c|c|}
\hline Covariate & OR & $\begin{array}{c}\mathbf{9 5 \%} \\
\mathbf{C I} \\
\text { Min }\end{array}$ & $\begin{array}{c}\mathbf{9 5 \%} \\
\mathbf{C I} \\
\mathbf{M a x}\end{array}$ & p-value \\
\hline ACE2-associated antineoplastic therapy & 0.65 & 0.00 & 0.98 & 0.04 \\
\hline Female gender & 0.79 & 0.00 & 1.01 & 0.06 \\
\hline Age greater than or equal to 65 & 1.04 & 0.81 & Inf & 0.43 \\
\hline Non-white race & 2.00 & 1.51 & Inf & 0.00 \\
\hline Smoking & 0.91 & 0.69 & Inf & 0.76 \\
\hline Hematologic malignancy & 2.89 & 2.02 & Inf & 0.00 \\
\hline Metastatic disease & 1.49 & 1.16 & Inf & 0.00 \\
\hline
\end{tabular}

Supp Tab. S4 | Multivariate logistic regression of study covariates in patients receiving active antineoplastic 275 therapy. Multivariate logistic regression analysis of covariates demonstrating statistical significance $(p \leq 0.10)$ in univariate analysis were included in a multivariate logistic regression. ACE2-associated antineoplastic therapy shows a trend towards significance (OR 0.68, 95\% CI 0.41-1.07, BH-corrected q-value of 0.13 ).

\begin{tabular}{|c|c|c|c|c|c|}
\hline Covariate & OR & $\begin{array}{c}\mathbf{9 5 \%} \\
\mathbf{C I} \\
\text { Min }\end{array}$ & $\begin{array}{c}\mathbf{9 5 \%} \\
\mathbf{C I} \\
\mathbf{M a x}\end{array}$ & p-value & $\begin{array}{c}\text { BH- } \\
\text { corrected } \\
\text { q-values }\end{array}$ \\
\hline ACE2-associated antineoplastic therapy & 0.68 & 0.40 & 1.07 & 0.11 & 0.13 \\
\hline Non-white race & 2.02 & 1.46 & 2.77 & 0.00 & 0.00 \\
\hline Hematologic malignancy & 2.62 & 1.70 & 3.93 & 0.00 & 0.00 \\
\hline Female gender & 0.76 & 0.57 & 1.03 & 0.07 & 0.12 \\
\hline Metastatic disease & 1.26 & 0.93 & 1.69 & 0.13 & 0.13 \\
\hline
\end{tabular}

280 Supp Tab. S5 | Major antineoplastic subcategorization key. Patient classification mapping shown for specific antineoplastic drugs used by patients in the "No ACE2-associated antineoplastic cohort" and their respective antineoplastic subcategory used in Supplementary Table S2.

[ See supplementary Excel file] 
medRxiv preprint doi: https://doi.org/10.1101/2020.09.02.20186783; this version posted September 3, 2020. The copyright holder for this preprint (which was not certified by peer review) is the author/funder, who has granted medRxiv a license to display the preprint in perpetuity. All rights reserved. No reuse allowed without permission.

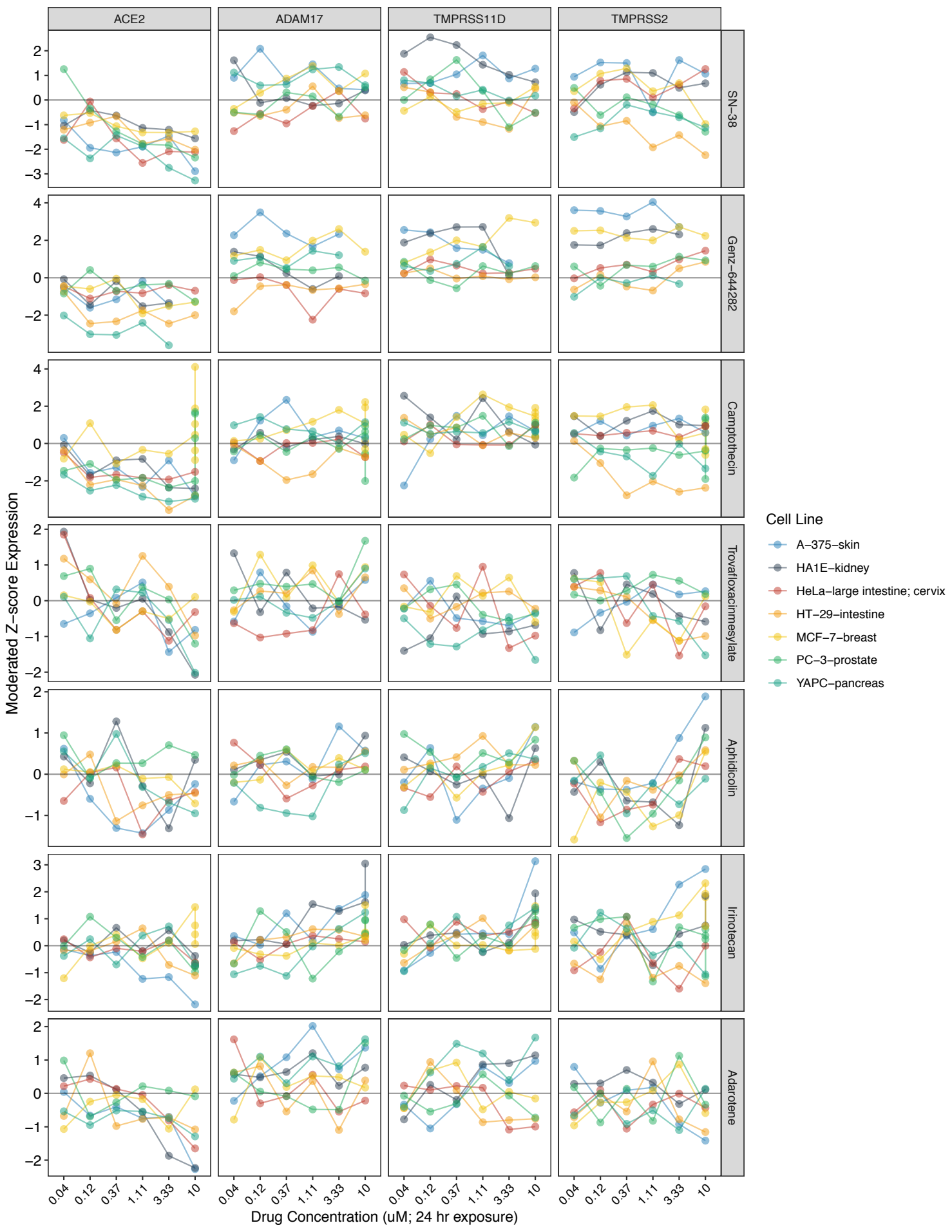

285 Fig. 1 | ACE2 expression reductions associated with exposure to various topoisomerase inhibitors. Related genes (ADAM17, TMPRSS11D, TMPRSS2) included for comparison. Y-axis (left) = moderated Z-scores summarizing differential expression across multiple replicates per cell line calculated by the LINCS project. Y-axis (right) $=$ drug name. 
medRxiv preprint doi: https://doi.org/10.1101/2020.09.02.20186783; this version posted September 3, 2020. The copyright holder for this preprint (which was not certified by peer review) is the author/funder, who has granted medRxiv a license to display the preprint in perpetuity.

All rights reserved. No reuse allowed without permission.

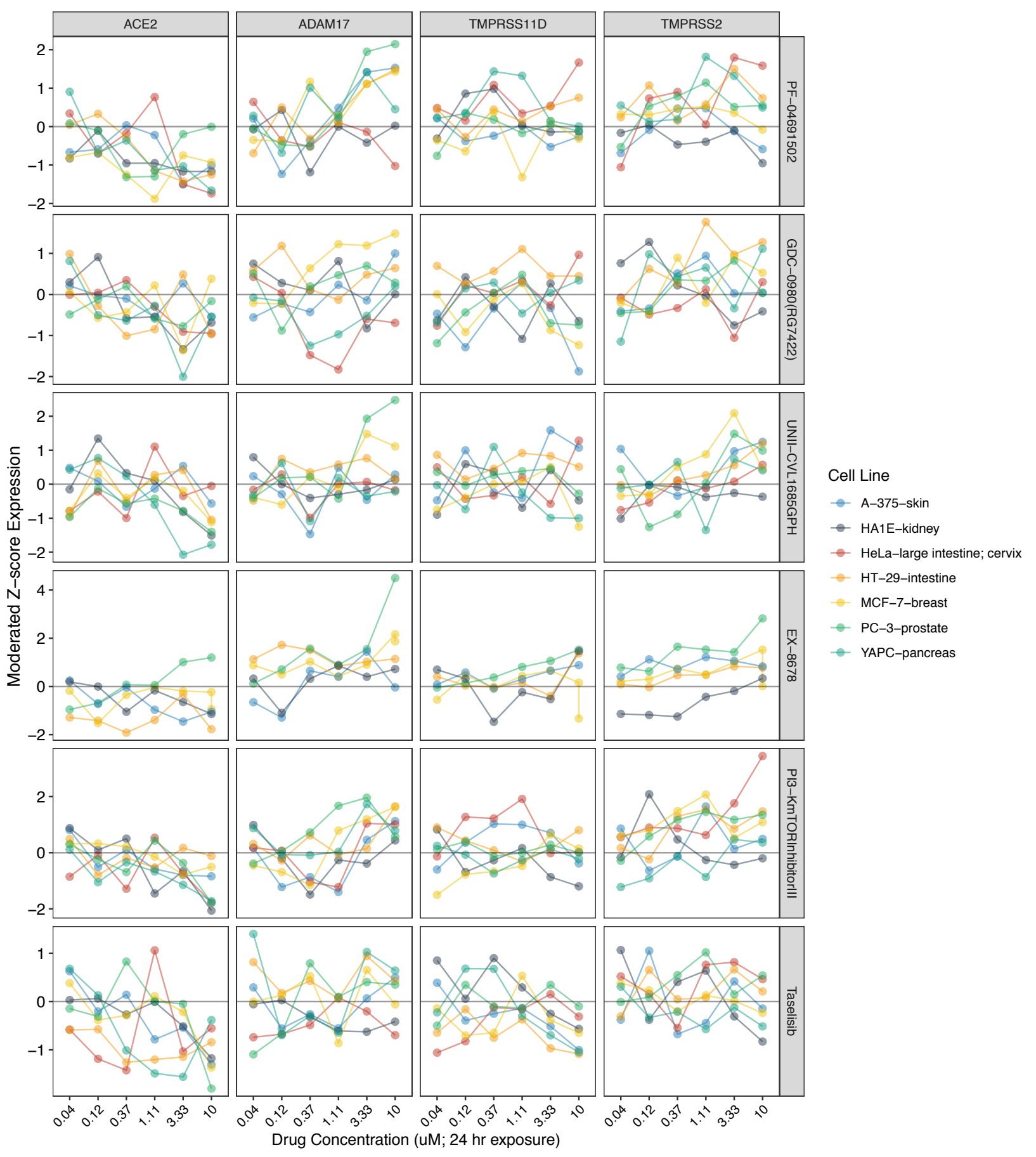

Fig. 2 | ACE2 expression reductions associated with exposure to PI3K/mTOR inhibitors. Related genes (ADAM17, TMPRSS11D, TMPRSS2) included for comparison. Y-axis = moderated Z-scores summarizing differential expression across multiple replicates per cell line calculated by the LINCS project. Y-axis (right) = drug name. 